\title{
The Influence of Hospital Image and Service Quality on Discharge Against Medical Advice through Patient Satisfaction
}

\author{
Sitti Harma \\ Student of Magister Program of Management, STIE AMKOP, Makassar, Indonesia \\ sitti.harma@gmail.com \\ IKhsan Kadir, Mansur Azis \\ STIE AMKOP, Makassar, Indonesia \\ ikhsankadir@gmail.com,mansurazis@gmail.com \\ Ira Liasari \\ Poltekkes Kemenkes, Makassar, Indonesia \\ ira.liasari@gmail.com \\ Yusriadi Yusriadi \\ Sekolah Tinggi Ilmu Administrasi Puangrimaggalatung, Makassar, Indonesia \\ hasnawatialimuddin@gmail.com, yusriadi.yusriadi@uqconnect.edu.au

\section{Chairun Nasirin} \\ College of Health Sciences (STIKES), Mataram, Indonesia \\ chairun.nasirin@stikes-mataram.ac.id \\ Rudy Kurniawan \\ University of Sriwijaya, Palembang, Indonesia \\ rudykurniawan@fisip.unsri.ac.id
}

\begin{abstract}
The purpose of this study is to examine the impact of hospital image and quality of service on Discharge Against Medical Advice (DAMA) via patient satisfaction at Majene District Hospital. This research was performed in the hospital room of the Majene District Hospital from July to August 2020. The type of analysis used is quantitative research to explain the dependent variable's effect on the independent variable and the mediating variable. This study population was all 102 patients with DAMA at Majene Hospital, as the population was deemed limited and the whole population was sampled. The test results of the coefficient of determination of the path analysis of substructure 1 resulted in a modified $\mathrm{R}$ square value of 0.235 . In this case, it is argued that patient satisfaction is affected by the hospital picture and quality of service by 23.5 percent. In comparison, the remaining 76.5 percent is influenced by other variables not analysed in this review. The outcome of the measurement of standardized beta coefficients, the effect of the hospital picture (X1) on patient satisfaction (Y1) is 0.228 , and the service quality (X2) on patient satisfaction (Y1) is 0.325 .
\end{abstract}

\section{Keywords:}

Hospital image, service quality, patient satisfaction, and Discharge Against Medical Advice (DAMA) 


\section{Bibliography}

Sitti Harma is a student at Magister Program of Management of STIE AMKOP, Indonesia. Her areas of interest and research include social science and economic. She has published some articles in national journals

Ikhsan Kadir is a lecturer at Economics Department of STIE AMKOP, Indonesia. His areas of interest and research include economic, management, management human resource. He has published some books and many articles in national and international journals. He is a reviewer and editor in some local and international journals.

Mansur Azis is a lecture at Economics Department of STIE AMKOP, Indonesia. His areas of interest and research include social science, economic and management. He has published some articles in national and international journals.

Ira Liasari is a lecture at Public Health of Poltekkese Kemenkes, Makassar, Indonesia. Her areas of interest and research include public health. She has published some articles in national and international journals.

Yusriadi Yusriadi is a lecturer at Public Administration Department of Sekolah Tinggi Ilmu Administrasi Puangrimaggalatung, Indonesia and chancellor on Sekolah Tinggi Ilmu Hukum Pengayoman. His areas of interest and research include social science, political science, sociology, legal studies, and public administration. He has published some books and many articles in national and international journals. He is a reviewer and editor in some local and international journals.

Chairun Nasirin is a lecturer at College of Health Sciences (STIKES Mataram), Indonesia. His research is related to health administration and health policy. Some of his research interests include health administration, community nursing, empowerment, health policy, and public health.

Rudy Kurniawan is a lecturer and researcher at the Faculty of Social and Political Studies, University of Sriwijaya, Palembang, Indonesia. Some of his research is related to sociology and society empowerment. His research interests include corporate social responsibility, resolution of conflict, and government studies. 